Report

\title{
Discovery of Cyrtospirifer (Late Devonian Brachiopoda) from Choanji in the South Kitakami Belt, northeastern Japan
}

\section{Jun-ichi Tazawa*}

Received August 30, 2016

Accepted November 30, 2016

Hamaura-cho 1-260-1, Chuo-ku, Niigata 951-8151, Japan

Corresponding author: J. Tazawa,

j1025-tazawa@memoad.jp

\begin{abstract}
Three Cyrtospirifer species (Cyrtospirifer choanjiensis sp. nov., Cyrtospirifer sp. 1 and Cyrtospirifer sp. 2) are described for the first time from Choanji, eastern part of the South Kitakami Belt, northeastern Japan. The occurrence of the Late Devonian brachiopod Cyrtospirifer from Choanji indicates the presence of Upper Devonian rocks in the Choanji area.
\end{abstract}

Keywords: brachiopod, Choanji, Cyrtospirifer, South Kitakami Belt, Upper Devonian

\section{Introduction}

Choanji (Hikoroichi-cho, Ofunato City, Iwate Prefecture), located in the eastern part of the South Kitakami Belt (Fig. 1), is a renowned fossil locality. The following marine invertebrate fossils have been previously described from sandstone at Choanji: one species of conulariid (Sugiyama, 1938, 1942); seven species of bryozoan (Sakagami, 1962); thirteen species of brachiopod (Minato, 1951, 1952); one species of pelecypod (Minato, 1951) and seven species of trilobite (Sugiyama, 1944; Okubo, 1951a; Endo and Matsumoto, 1962; Kobayashi and Hamada, 1980). The Choanji fauna has been considered the earliest Carboniferous (early Tournaisian) fauna in the South Kitakami Belt and in the whole of Japan (Minato, 1950; Okubo, 1951b; Minato and Kato, 1979).

Recently, I recognized some brachiopod specimens from Choanji belonging to the genus Cyrtospirifer in my brachiopod collection. Cyrtospirifer is one of the most widespread cyrtospiriferid genera: about 150 species (including varieties) of the genus have been described from the Upper Devonian of worldwide (Ma and Day, 2003). The range of Cyrtospirifer is now considered to be Late Devonian (Frasnian-lower Famennian; Johnson, 2006). Therefore, the occurrence of Cyrtospirifer from Choanji indicates a Late Devonian age for the Choanji fauna and it implies the presence of Upper Devonian rocks in the Choanji area.

In this study, three Cyrtospirifer species (Cyrtospirifer choanjiensis sp. nov., Cyrtospirifer sp. 1 and Cyrtospirifer sp. 2) from Choanji are described and their stratigraphic significance is noted. The brachiopod specimens described herein are registered with the prefix NU-B, and housed in the Department of Geology, Niigata University, Niigata.

\section{Stratigraphy}

The brachiopod fossils were collected by the present author from bluish-grey, tuffaceous, fine-grained sandstone at locality CHJ1 $\left(39^{\circ} 06^{\prime} 23^{\prime \prime} \mathrm{N}, 141^{\circ} 41^{\prime} 21^{\prime \prime} \mathrm{E}\right)$, an outcrop near the mouth of the Kogayosawa Valley, a tributary of the Sakarigawa River.

The fossil-bearing sandstone at Choanji was initially assigned to the basal part of the Carboniferous Tyoanzi (Choanji) Group (Yabe and Sugiyama, 1937), on the basis of the presence of certain brachiopods; e.g., Productus cf. semireticulatus Martin [= Dictyoclostus cf. semireticulatus (Martin, 1809)]. Subsequently, Minato (1950) and Okubo (1951b) regarded the sandstone as being the lowest part of the Lower Carboniferous (Tournaisian) Hikoroichi Series, based on the Choanji fauna (mostly on the brachiopods) and on lithological correlations between the DevonianCarboniferous rocks of the Choanji area and the Hikoroichi area, which is located immediately west of Choanji. Consequently, the latter proposal has been generally accepted (e.g., Minato et al., 1979; Kawamura, 1989). However, little is known about the Devonian-Carboniferous stratigraphy of the Choanji area, owing to a lack of the paleonotological and stratigraphical data.

In this paper, I regard the Cyrtospirifer-bearing sandstone as part of the Upper Devonian (tentatively named as the Choanji Formation) which is distributed in around the fossil locality.

\section{Systematic descriptions}

Order Spiriferida Waagen, 1883

Suborder Spiriferidina Waagen, 1883 


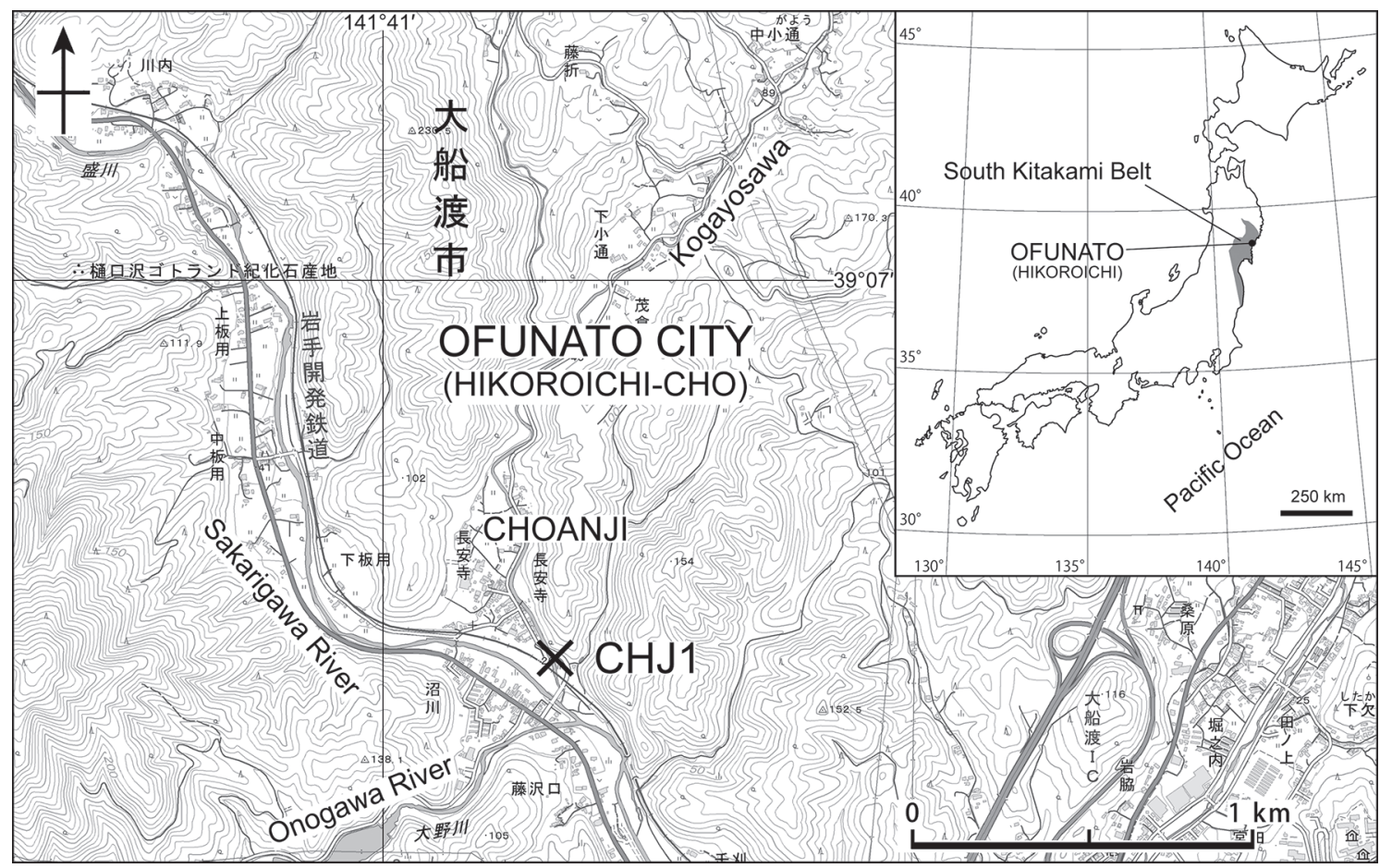

Fig. 1. Map showing the fossil locality CHJ1, at Choanji, eastern part of the South Kitakami Belt, northeastern Japan (using the topographic map of GSI).

Superfamily Cyrtospiriferoidea Termier and Termier, 1949

Family Cyrtospiriferidae Termier and Termier, 1949 Subfamily Cyrtospiriferinae Termier and Termier, 1949

Genus Cyrtospirifer Nalivkin in Fredericks, 1924

Type species. - Spirifer verneuili Murchison, 1840.

Cyrtospirifer choanjiensis sp. nov.

Fig. 2. 1

Cyrtospirifer sp. B. Tazawa, Yang and Miyake, 2000, p. 731, figs. 5.5-5.8.

Etymology.-Named after the fossil locality, Choanji.

Material.-One specimen from locality CHJ1, external and internal moulds of a dorsal valve, NUB2236 (holotype).

Diagnosis.-Small-sized Cyrtospirifer, with a low flattened dorsal fold bounded by deep furrows, and micro-ornament of very fine growth lines.

Description.-Shell small in size for genus, wider than long, cardinal extremities acute; length about 23 $\mathrm{mm}$, width about $33 \mathrm{~mm}$ in the dorsal valve of the holotype (NU-B2236). Dorsal valve slightly convex in both lateral and anterior profiles; fold low, clearly demarcated from flanks by a pair of deep furrows. External surface of dorsal valve ornamented with numerous simple, often bifurcated costae, numbering 20 or more per flank (7-8 in $5 \mathrm{~mm}$ at $15 \mathrm{~mm}$ from umbo), and 9 on fold; micro-ornament of very fine growth lines over valve. Internal structure of dorsal valve not well preserved.

Remarks.-Cyrtospirifer choanjiensis sp. nov. most resembles Cyrtospirifer gneudnaensis Glenister (1955, p. 66, pl. 5, figs. 6-27; pl. 6, figs. 1-20; text-figs. 1.5-1.10, 4.15-4.18), from the Gneudna Formation (Frasnian) of the Carnarvon Basin, western Australia, in the small size and the flattened dorsal fold, but differs from the Australian species in having very fine growth lines and lacking radial striations on both furrows and costae. Cyrtospirifer sp. B, described by Tazawa et al. (2000) from the Rosse Formation of the Moribu area, Hida Gaien Belt, central Japan, is deemed conspecific with the present species. Cyrtospirifer thalattodonta Crickmay (1952, p. 601, pl. 72, figs. 1-8), from the Hay River Formation (Famennian) of northern Canada, also has micro-ornament consisting of numerous fine growth lines, but differs from $C$. choanjiensis in the much larger dimensions and the highly developed dorsal fold. Cyrtospirifer yabei Noda and Tachibana (1959, p. 17, pl. 1, figs. 1-7, 10), most common Cyrtospirifer species in the Tobigamori Formation of the Nagasaka area, 

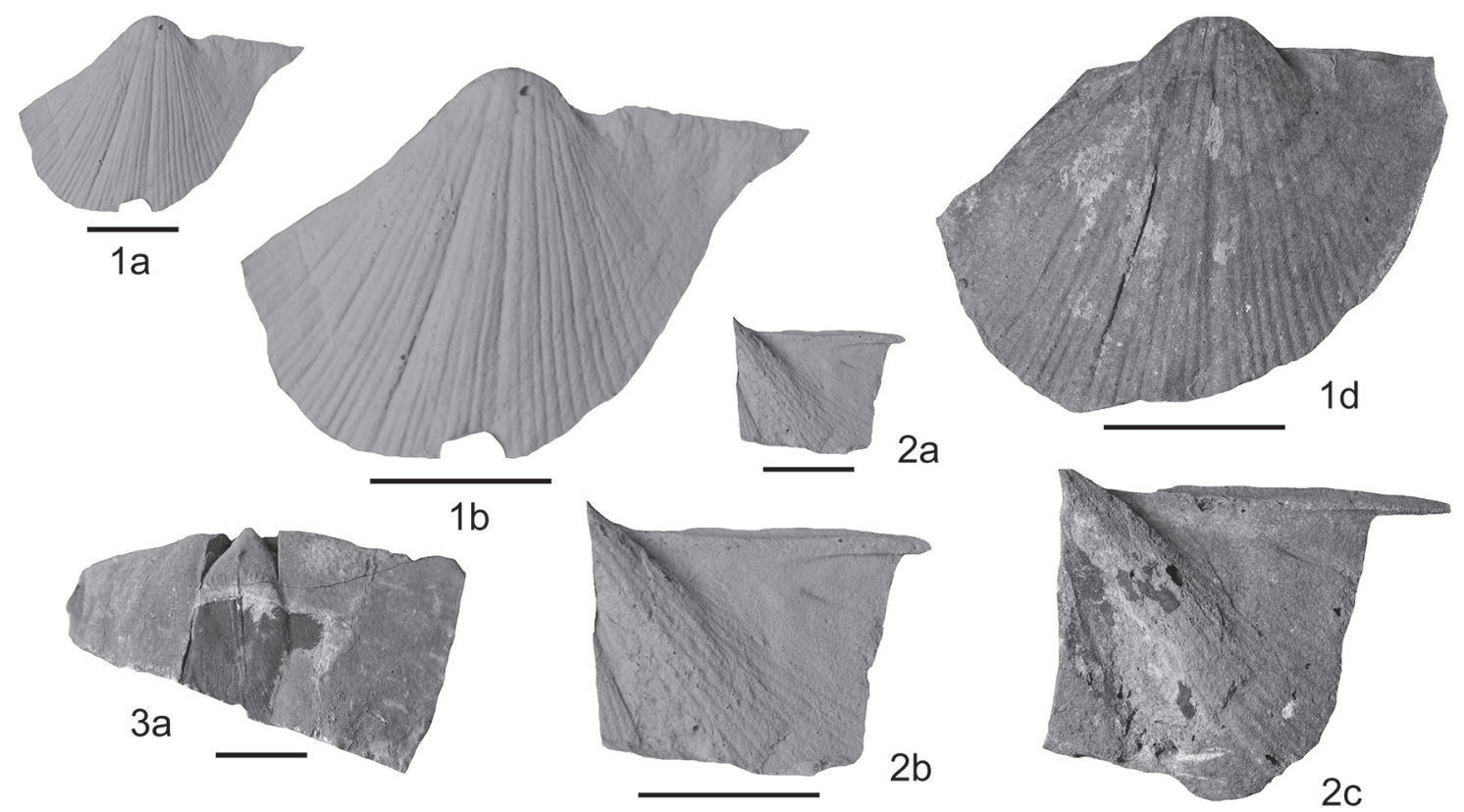

$2 a$
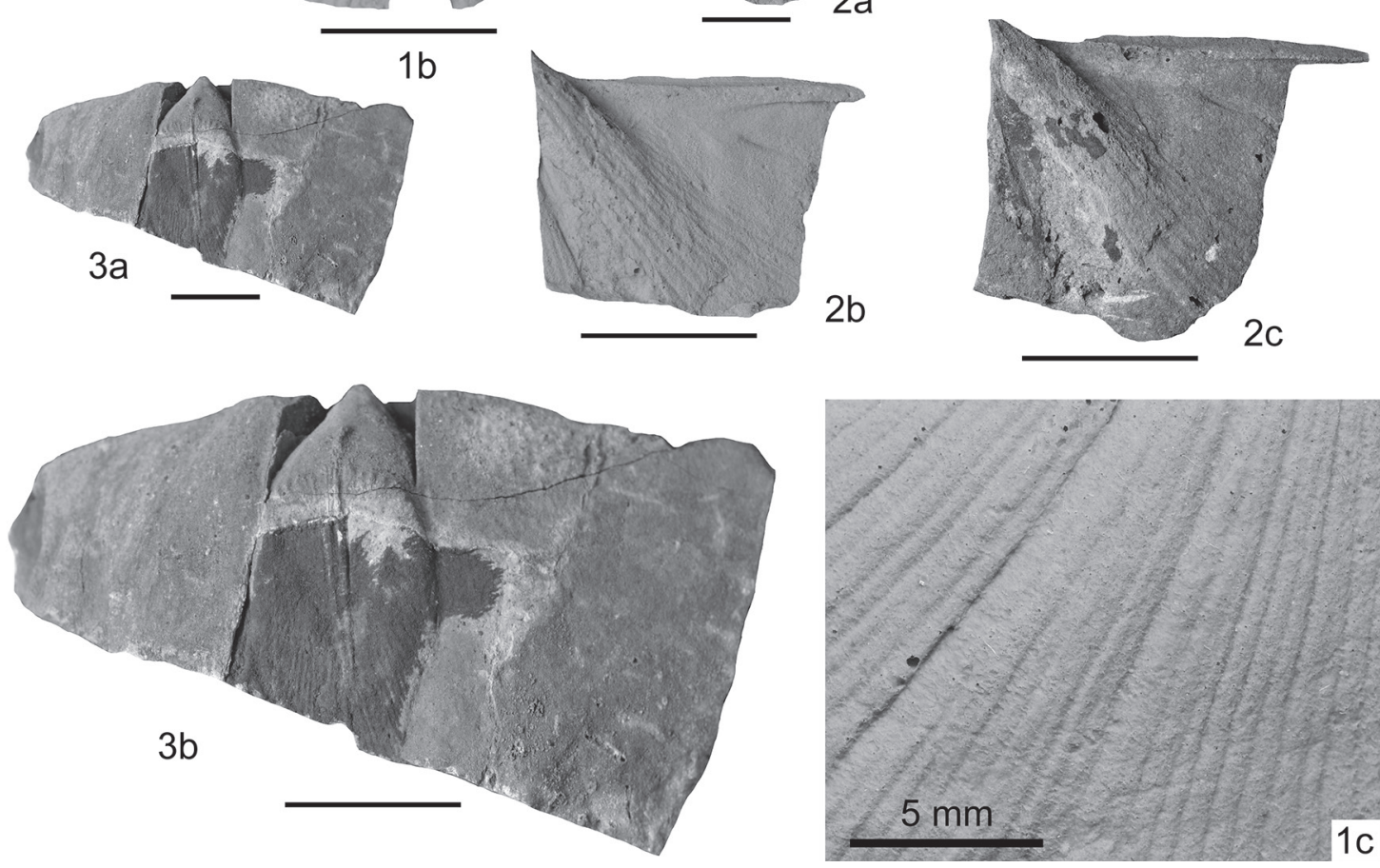

Fig. 2. 1, Cyrtospirifer choanjiensis sp. nov., dorsal view $(1 \mathrm{a}, 1 \mathrm{~b})$ of external latex cast and enlarged one (1c) showing concentric growth lines, and dorsal view (1d) of internal mould of dorsal valve, NU-B2236 (holotype). 2, Cyrtospirifer sp. 1, ventral view $(2 \mathrm{a}, 2 \mathrm{~b})$ of external latex cast of ventral valve, and ventral view (2c) of internal mould of dorsal valve, NU-B2237. 3, Cyrtospirifer sp. 2, ventral view (3a, 3b) of internal mould of ventral valve, NU-B2238. Scale bars represent $1 \mathrm{~cm}$, except for $1 \mathrm{c}$.

western part of the South Kitakami Belt, is readily distinguished from the present species in the much larger dimensions and in having dorsal fold with a median depression.

\section{Cyrtospirifer sp. 1}

Fig. 2. 2

Material.-One specimen, external and internal moulds of a ventral valve, NU-B2237.

Remarks. - This specimen is safely referred to the genus Cyrtospirifer by the medium-sized (length about $18 \mathrm{~mm}$, width about $45 \mathrm{~mm}$ ), transversely subquadrate ventral valve with mucronate cardinal extremities and ornamented by numerous simple costae over the valve. The Choanji specimen resembles well the ventral valve, figured by Sarytcheva and Sokolskaya (1952, p. 182, pl. 50, fig. 279) as Spirifer disjunctus Sowerby [=Cyrtospirifer disjunctus (Sowerby, 1840)], from the Semiluki Horizon (lower Frasnian) of the Moscow Basin, western Russia, in size and shape of the ventral valve and in having prominent cardinal extremities. However, accurate comparison is difficult owing to ill preservation of the present material.

\section{Cyrtospirifer sp. 2}

Fig. 2.3

Material.-One specimen, internal mould of a ventral valve, NU-B2238.

Remarks. - This specimen is safely assigned to the genus Cyrtospirifer by the large size (length more than 
$30 \mathrm{~mm}$, width more than $45 \mathrm{~mm}$ ), wider subrectangular outline, and moderately convex ventral valve, with a pair of long, thick and slightly divergent dental plates. The Choanji species is large in size for the genus, and superficially resembles some large-sized Cyrtospirifer species, e.g., Cyrtospirifer verneuili var. gosseleti (Grabau, 1931), Cyrtospirifer thalattodoxa Crickmay, 1952 and Cyrtospirifer subextensoides Ma, 2009. But due to the poor preservation, it is not possible to assign the present material to one of these species.

\section{Acknowledgements}

Sincere thanks are due to Yousuke Ibaraki (Fossa Magna Museum, Itoigawa) for his help in drawing the figures, and two anonymous reviewers for critical reading of the manuscript.

\section{References}

Crickmay, C. H., 1952, Discrimination of late Upper Devonian. Jour. Paleontol., 26, 585-609.

Endo, R. and Matsumoto, E., 1962, Permo-Carboniferous trilobites from Japan. Sci. Rep. Saitama Univ., Ser. B, 4, 149-172.

Fredericks, G. N., 1924, Paleontological studies, 2: On Upper Carboniferous spiriferids from the Urals. Izv. Geol. Kom., 38, 295-324.**

Glenister, B. F., 1955, Devonian and Carboniferous spiriferids from the North-West Basin, western Australia. Jour. Roy. Soc. W. Aust., 29, 46-71.

Grabau, A. W., 1931, Devonian Brachiopoda of China. Palaeont. Sinica, Ser. B, 3, 1-753.

Johnson, J. G., 2006, Cyrtospiriferoidea. In Kaesler, R. L., ed., Treatise on Invertebrate Paleontology, Part H Brachiopoda Revised, Volume 5: Rhynchonelliformea (Part), Geol. Soc. Am., Boulder and Univ. Kansas, Lawrence, 1722-1732.

Kawamura, T., 1989, §2.1.4. Kitakami Mountains; Carboniferous System. In Editorial Committee of Tohoku, ed., Regional Geology of Japan, Part 2. Tohoku, Kyoritsu Shuppan, Tokyo, 17-23.*

Kobayashi, T. and Hamada, T., 1980, Carboniferous trilobites of Japan in comparison with Asian, Pacific and other faunas. Palaeontol. Soc. Japan, Spec. Pap., no. 23, 1-132.

Ma, X., 2009, Spiriferide brachiopods from the Frasnian (Devonian) of the Dushan area, southern Guizhou, China. Acta Palaeontol. Sinica, 48, 611-627.

Ma, X. and Day, J., 2003, Revision of selected North American and Eurasian Late Devonian (Frasnian) species of Cyrtospirifer and Regelia (Brachiopoda). Jour. Paleontol., 77, 267-292.

Martin, W., 1809, Petlificata Derbiensia; or Figures and Descriptions of Petrefactions Collected in Derbyshire. D. Lyon, Wigan, 28p.

Minato, M., 1950, Stratigraphische Stellung der Hikoroiti-Serie. Jour. Geol. Soc. Japan, 56, 143-148.*

Minato, M., 1951, On the Lower Carboniferous fossils of the Kitakami Massif, northeast Honsyu, Japan. Jour. Fac. Sci., Hokkaido Univ., Ser. 4, 7, 355-382.

Minato, M., 1952, A further note on the Lower Carboniferous fossils of the Kitakami Mountainland, northeast Japan. Jour. Fac. Sci., Hokkaido Univ., Ser. 4, 8, 136-174.

Minato, M. and Kato, M., 1979, §2f.3. Tournaisian; Biostratigraphy and correlations. In Minato, M., Hunahashi,
M., Watanabe, J. and Kato, M., eds., Variscan Geohistory of Northern Japan: The Abean Orogeny, Tokai Univ. Press, Tokyo, 80-81.

Minato, M., Takeda, H., Kato, M., Suetomi, H., Hirata, Y., Kawamura, M. and Haga, S., 1979, §2f.2. Tournaisian; Stratigraphy. In Minato, M., Hunahashi, M., Watanabe, J. and Kato, M., eds., Variscan Geohistory of Northern Japan: The Abean Orogeny, Tokai Univ. Press, Tokyo, 74-79.

Murchison, R. I., 1840, Description de quelques unes des coquilles fossiles les plus abondantes dans les couches devoniennes du Bas-Boulonnais. Bull. Soc. Géol. France, $11,250-256$.

Noda, M. and Tachibana, K., 1959, Some Upper Devonian cyrtospiriferids from the Nagasaka district, Kitakami Mountainland. Sci. Bull. Fac. Lib. Arts and Educ., Nagasaki Univ., no. 10, 15-21.

Okubo, M., 1951a, Trilobites from Japan. Earth Sci. (Chikyu Kagaku), no. 4, 133-139.*

Okubo, M., 1951b, Zur Hikoroichi-Serie und der bedeutenden Diskordanz vor der Hikoroichi-Epoche. Jour. Geol. Soc. Japan, 57, 159-209.*

Sakagami, S., 1962, Lower Carboniferous Bryozoa from the Hikoroichi Series, Japan. Trans. Proc. Palaeont. Soc. Japan, N. S., no. 46, 227-242.

Sarytcheva, T. G. and Sokolskaya, A. N., 1952, A description of the Paleozoic Brachiopoda of the Moscow Basin. Tr. Paleont. Inst., Akad. Nauk SSSR, 38, 1-307.**

Sowerby, J. de C., 1840, Explanation of plates. In, Sedgwick, A. and Murchison, R. I., eds., Physical structure and older stratified deposits of Devonshire, Geol. Soc. London, Trans., Ser. 2, 5, 633-703.

Sugiyama, T., 1938, A new Lower Carboniferous Conularia from the Kitakami Mountainland. Jour. Geol. Soc. Japan, 45, 771-773.

Sugiyama, T., 1942, Studies on the Japanese Conularida. Jour. Geol. Soc. Japan, 49, 390-399.

Sugiyama, T., 1944, On Japanese trilobites. Stud. Rep. Geol. Min. Inst., Tokyo Bunrika Daigaku, no. 1, 21-30.*

Tazawa, J., Yang, W.-P. and Miyake, Y., 2000, Cyrtospirifer and Leptophloeum from the Devonian Rosse Formation, Hida Gaien Belt, central Japan. Jour. Geol. Soc. Japan, 106, 727-735.*

Termier, H. and Termier, G., 1949, Essai sur l'évolution des spiriféridés. Notes du Serv. Geol., 74B, 85-112.

Waagen, W., 1883, Salt Range fossils, 1. Productus-Limestone fossils. Palaeont. Indica, Ser. 13, 1, 391-546.

Yabe, H. and Sugiyama, T., 1937, Preliminary report on the fossiliferous Gotlandian and Devonian deposits newly discovered in the Kitakami Mountainland. Proc. Imp. Acad. Tokyo, 13, 417-420.

*in Japanese

**in Russian

\section{用語対比}

Choanji

長安寺

Hikoroichi-cho

日頃市町

Kogayosawa Valley 小通沢

Moribu

森部

Nagasaka

長坂

Ofunato City

大船渡市

Rosse Formation 呂瀬層

Sakarigawa River 盛川

Tobigamori Formation 
科学論文では, 学説の検証可能性を保証することが重要です。そのため, 地質学雑誌掲載論文には, 重 要な証拠となった試料がどこで得られたかを示しているものがあります。言うまでもないことですが, 見学や採取を行う場合, 各自の責任において地権者や関係官庁への連絡と許可の取得の必要があること にご注意下さい。詳しくは，以下のサイトをご覧ください.

http://www.geosociety.jp/publication/content0073.html 